\title{
Recycling of Textiles in India
}

\section{Bairagi $\mathbf{N}^{*}$}

Department of Knitwear Design, National Institute of Fashion Technology, Bengaluru, India

\section{Introduction}

India is a country with people of different cultural background and community. According to Lucy [1] clothing is treated differently in India. Owing to the significant social meaning held by textiles, clothing is rarely discarded. Instead, it is frequently recycled for both the domestic and global markets.

Recycling of textiles was a domestic craft in India but currently there are textile clusters and small scale industries to work on second hand imported clothing and create a range of products like recycled yarns, doormats, prayer rugs, blankets and bed linen. The leftover garments are cut into square pieces to be sold as industrial wipers for the paints, chemicals and construction industries, for both local and international buyers in Japan and Australia. Waste is used to stuff pillows and mattresses. Bathroom mats that use recycled cotton yarn, is an INR 2,000 crore industry according to Handique [2].

Textile or apparel waste is generally categorized as either preconsumer or post-consumer waste. The pre-consumer waste consists of by-product material from the yarn, textile and apparel industries. Post-consumer textile waste mainly originates from household sources and consists of garments or textiles which the owner no longer needs as it was.

\section{Application of Pre-Consumer Textile Wastes}

The pre-consumer textile waste in India has a number of applications based on the fibre composition. Cotton waste has a number of applications like paper making, surgical products like bandages and pads, Open End spinning, automobile industry, tissue paper manufacturing or in the nonwoven industry, bedding, manuring for mushrooms, and more. Cotton waste is also exported to other foreign countries from India after it is cleaned and the required standard is attained. V P Udyog Limited, Kolkata, India is an exporter of refined cotton waste from comber noil and card, yarn waste, hosiery waste from India to countries like England, France, Malaysia, Thailand, China, Taiwan, Hong Kong and Singapore. Anandi Enterprises of Tirupur, India manufacture and export quality certified recycled dyed and mélange yarns and recycled fabrics from cotton and polyester. Industries like this produce contamination free waste that has varied applications across key industries [3].

The silk wastes from the export oriented silk industries in and around Bangalore, India are also bought by the small traders for manufacture of a number of silk accessories and products like bangles, scarfs, tassels, silk embroidery yarn, Christmas decors, etc.

\section{Recycling of Post-Consumer Textile Wastes}

Post-consumer textile wastes are recycled in the industrial sector as well as in almost every Indian household.

\section{Industrial recycling of textile wastes}

In the case of recycling of post-consumer wastes of wool and acrylic waste in India, Panipat, in northern India, is the world's largest textile recycling hub, producing reclaimed "shoddy" wool yarns and blankets out of used winter clothing. The raw material is sourced from the international second hand clothing market of the developed countries like USA \& UK. Small industries produce yarns, blankets, felt products cotton durries, made-ups, throws and mats. For example, Wilcox has estimated that up to $20 \%$ by volume of its turnover is exported to India for recycling. The business of using recycled acrylic and woollen threads for blanket manufacturing has annual revenues of INR 7001,000 crore in Panipat alone, according to the All India Woollen and Shoddy Mills' Association [2]. The trade is not illegal, as the clothing is mutilated before it crosses the Indian border.

Kishco Group, Mumbai, India deals with import and export business related to recycled clothing to serve various industries. Materials that are imported constitute residues of all types (cotton, acrylic, wool, polyester, nylon etc.) from different stages of production in the textile industry like fibre manufacture, yarns spinning, fabric weaving/ knitting, new garment manufacture, etc. Some of these materials are converted to fibres like poly waste yarn, poly-regenerated fibres, etc. Used clothing comprising of wool, acrylic and cotton sweater are converted into re-generated fibre by Kishco Group. According to Nohar Nath of Kishco group, the business of sorting and grading of textile consumer waste imported from the developed countries happens in the Kandla Special Economic Zone in Gujarat, 600 kilometres to the north of Kishco's Mumbai base. It is one of the largest centres of India where sorting and grading of textile wastes takes place. Some of the used clothing waste imported into India is also used for wiping material. The supplies mainly come in from U.S.A. and Europe [4].

\section{Recycling of Textile Wastes in Craft Clusters of India}

Post-consumer textiles wastes are also up-cycled in small Indian clusters. Traditionally, fabric from old cotton sarees are made into layers and stitched together using run stitches, to give a unique design effect. This product termed as "Kantha" is used for infants and children as blankets and wraps as it is soft and suitable for the Indian climatic conditions [5]. Kantha work is famous in the eastern states of India like Bihar, West Bengal, Assam and Orissa (Figure 1). The nomadic Bakkarwal and Gujjar tribes of Jammu and Kashmir use acrylic yarn for embroidery on the old woolen felt blankets and convert it in to a beautiful needle worked handmade rugs. This is a part of their tradition and culture and a method to preserve the old textiles. They also use old textiles to make caps, bags and other accessories with beautiful hand embroidery as seen in Figure 2 [6]. Similarly, the nomadic tribes in Rajasthan, India do patch work, embroidery and mirror work to give a bright new look to their dresses (Figure 3). A number of accessories are also created on recycled textiles with surface embellishment by

*Corresponding author: Bairagi N, Department of Knitwear Design, National Institute of Fashion Technology, Bengaluru, India, Tel: 080-225-525-505; E-mail: nilanjana.bairagi@nift.ac.in

Received April 03, 2014; Accepted May 02, 2014; Published May 05, 2014

Citation: Bairagi N (2014) Recycling of Textiles in India. J Textile Sci Eng S2: 003. doi:10.4172/2165-8064.S2-003

Copyright: ( 2014 Bairagi N. This is an open-access article distributed under the terms of the Creative Commons Attribution License, which permits unrestricted use, distribution, and reproduction in any medium, provided the original author and source are credited. 


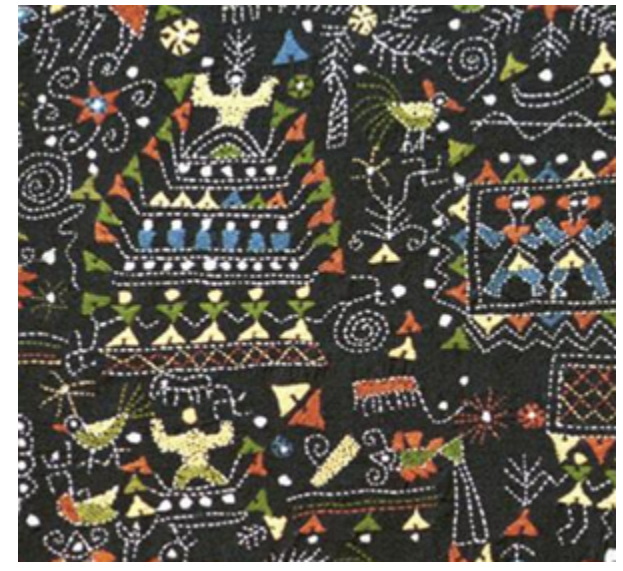

Figure 1: Kantha stitch on cotton fabric.

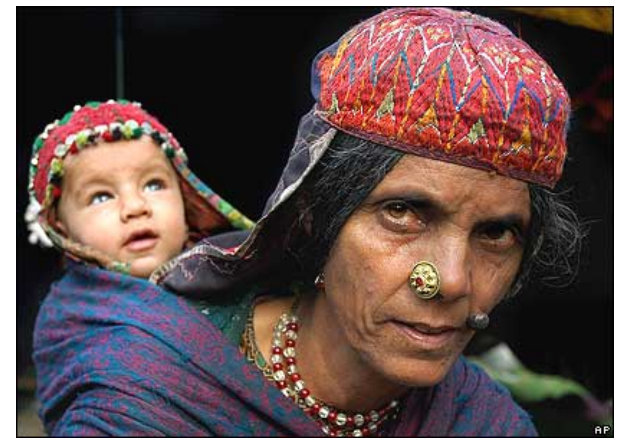

Figure 2: Recycled caps with hand embroidery of the Bakkarwal tribes of Jammu \& Kashmir, India.

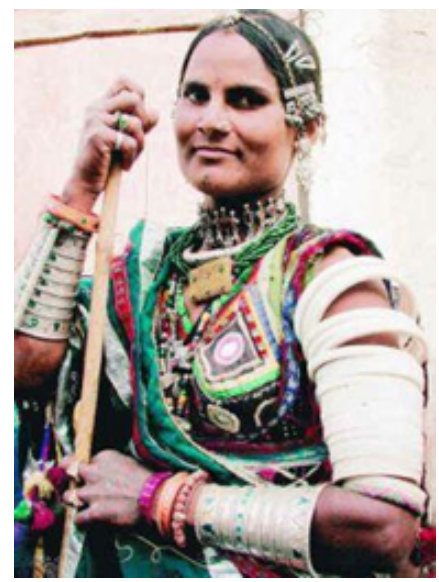

Figure 3: Patch work on old clothing in Rajasthan, India.

this community and marketed by different NGOs and traders for the domestic \& international market (Figure 4) [7].

Yarns from industrial waste pieces of knitted fabric or old knitted clothing is used as weft and made in to door mats and rugs in small clusters of India (Figure 5).
Upcycling of old textiles specially Indian sarees/saris (which is 5.5 meters long piece of fabric) to cushion covers, bags, table covers, blankets by quilting is a common practice at present in many places all over India.

\section{Recycling of Textile Wastes in Households of India}

Old textiles, mostly cotton are often converted to wipes, kitchen towels, dusting cloth, in Indian households. If the garments are in a good condition they are generally passed down to the under privileged people. Garments are collected by different NGOs to distribute to the people after a natural calamity like floods.

\section{Conclusion}

Textiles in India are recycled both for the domestic and the global market. In the domestic market recycled textile products are generally found in the form of floor mats, wipes and rugs. The fibres extracted during recycling of clothing are converted into recycled yarns and it is used in different textile products and also as fillers. The pre-consumer cotton wastes are a source of raw material for the paper industry. Recycled silk yarns are converted to a number of small products and accessories. The recycling of woolen and acrylic products in Panipat is the biggest textile recycling industrial cluster in India. Sorting and grading of textile wastes for the industrial sector also happens in Kandla Special Economic Zone, Gujarat. Apart from this old textiles are upcycled into a number of innovative products using traditional Indian embroidery in the craft clusters and households, or passed down to the under privileged in a developing country.

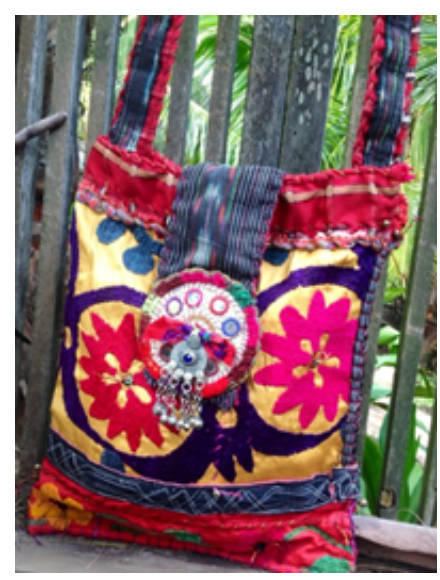

Figure 4: Patch work product.

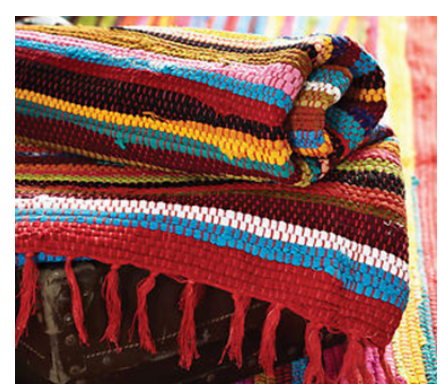

Figure 5: Rugs made from recycled weft yarn (from knitted waste fabric). 


\section{References}

1. Norris L (2010) Recycling Indian Clothing: Global Contexts of Reuse and Value. Indiana University Press, Bloomington, USA.

2. Handique M (2010) Old clothes spin a new yarn in India. Live Mint \& the Wall Street Journal, USA.

3. http://www.vpudyog.com/cotton_waste/
4. http://www.kishcogroup.com/wipers.html.

5. Lalita (2014) Personal interview. Textiles- Barddhaman, West Bengal, India.

6. Roy A (2012) Personal interview. Textiles-New Delhi, India.

7. Gupta $\vee(2012)$ Recycling of textile waste in small clusters and its contribution to the socio-economic upliftment of the community. AsialnCH Encyclopedia, India. 